\title{
The Legal Context
}

Abstract This chapter gives a brief introduction into late medieval Kampen, the archival sources used in the study, an overview of the historical and legal background of banishment in the Low Countries and a discussion of the by-laws concerning the topic. It also includes a brief description of the images illustrating the contents of one of the manuscripts used, some of which are included in this book.

Keywords Local laws • Local administration

\section{Kampen And Its Sources}

In the late middle ages, especially from the mid-thirteenth to the midfifteenth century, Kampen was one of the main trading towns in the northern Netherlands, with an estimated population of c.6000-8500 in the fifteenth century. ${ }^{1}$ A sometimes reluctant member of the Hanse for at least part of this period, the town was situated near the mouth of the River IJssel, which connected the Rhine to the Zuiderzee and the North Sea beyond. ${ }^{2}$ As such, Kampen functioned as an entrepot for trade to and

${ }^{1}$ Between 6120 and 8440 according to Van der Vlis, 'De bevolking van Kampen', 14.

${ }^{2}$ Kampen was (re)admitted into the Hanse in 1441, but had shared in the rights and privileges of the Hanse before then and was present at a large number of Hanseatic diets, though less so in the decades directly before 1441. At other times the town did not cooperate with

(C) The Author(s) 2022

E. Frankot, Banishment in the Late Medieval Eastern Netherlands, https://doi.org/10.1007/978-3-030-88867-1_2 
from the Rhine. ${ }^{3}$ In addition, Kampen's ships could be found all the way along northern and western shores, where they transported goods from the Baltic towns to Bruges and further south. In fact, some authors have argued that most 'Kampen' trade took place outside the town itself and that many Kampen skippers (and possibly their ships) only wintered in their hometown. ${ }^{4}$ In the second half of the fifteenth century Kampen's position may have stagnated somewhat as a result of competition from merchants and ships from Holland and Zeeland in the transportation between east and west. These towns eventually surpassed the IJssel towns. In 1503, for example, the Sound toll registers show 48 Kampen ships sailing past Elsinore, against 116 from Amsterdam and 331 from Holland. ${ }^{5}$ The silting of the IJssel estuary may also have been an issue. But, as will also become clear later, ${ }^{6}$ Kampen was still doing well economically in the second half of the fifteenth century, and an actual decline did not occur until the early sixteenth century as a result of conflicts between the dukes of Burgundy/Habsburg and Guelders between 1497 and 1520. ${ }^{7}$

Kampen was situated in the Sticht province in the eastern Netherlands, which was part of the Utrecht diocese, and which included a number of Hanseatic towns with whom Kampen collaborated, such as nearby Zwolle, and Deventer further up the IJssel river. The town had been largely autonomous since the late thirteenth and early fourteenth centuries when it was able to make use of the troubles of its lord, the bishop of Utrecht, to acquire extensive privileges. Important within the context of this study is the privilege granted in 1309, which provided the magistrates with full jurisdiction in legal matters. ${ }^{8}$ Thieves, murderers and those that threatened the town's authority could be tried, sentenced and punished in Kampen itself. A few years earlier, in 1302, the bishop had already granted

or even worked against other Hanseatic towns. Weststrate, In het kielzog van moderne markten, 40-43; Frankot, Medieval Maritime Law, 60-61, and n. 40.

${ }^{3}$ The importance of the Rhenish trade is clear from the amount of 'rijnscippers' (Rhine skippers) mentioned in the sources. In the Liber Testium, for example, Rhine skippers appear nineteen times in testimonies concerning criminal cases between 1483 and 1493 , referring to ten individuals. LT, ff. $2 \mathrm{v}, 52 \mathrm{v}, 72 \mathrm{r}, 75 \mathrm{v}, 81 \mathrm{r}, 116 \mathrm{r}, 137 \mathrm{r}, 138 \mathrm{r}, 141 \mathrm{r}, 143 \mathrm{r}, 144 \mathrm{r}, 200 \mathrm{v}$.

${ }^{4}$ Tamse, 'Economische geschiedenis van Kampen', 213, also referring to Meilink (though without a specific reference).

5 Tamse, 'Economische geschiedenis van Kampen', 219.

${ }^{6}$ See the openness to immigrants and continuing admission of new citizens in Chap. 5 .

${ }^{7}$ Tamse, 'Economische geschiedenis van Kampen', 219, 224, 232, 234, 237; Grooten, 'Kampen an der IJssel', 300-301; Frankot, Medieval Maritime Law, 58-61.

${ }^{8}$ Kossmann-Putto, Kamper schepenacten, 3-4. 
the privilege that Kampen inhabitants could not be tried before a church court in worldly matters. What these worldly matters exactly included was an issue that was contested between the church and urban courts. The traditional church jurisdiction in cases of adultery, perjury, usury and other matters was challenged by the urban authorities relatively early in the Utrecht diocese. ${ }^{9}$ Judging by the sources from the second half of the fifteenth century, they appear to have been successful in this challenge. A variety of issues related to marriage were dealt with by the urban courts, as was perjury.

In the later middle ages, the town was governed by 12 aldermen (schepenen), supported by 12 councillors (raden). The aldermen elected their successors each year (often these were the past year's councillors), while they themselves became councillors. In practice the town was governed by a small group of men, many of whom were members of the rich merchant families. ${ }^{10}$ The 'sworn community' (gesworen ghemeynte), representing the burghers and consisting of prominent burghers and guild masters, also had a vote in matters of town law and finance. Daily government was conducted by two burgomasters. These were both aldermen and were appointed for a month at a time. These burgomasters also administered justice in the lower court where certain civil cases and fineable offences were dealt with. Appeals and the more serious crimes were handled by the higher court consisting of the aldermen. A higher appeal court consisted of the full board of aldermen and councillors. ${ }^{11}$ Originally, a bailiff, as the representative of the bishop, was involved in the administration of justice in capital offences, ${ }^{12}$ but there is little evidence of his involvement in the years covered by this study.

A more informal role, that was nonetheless important and confirms the comments made in the introduction on the collaboration between the town magistrates and various groups in society, was played by the 'good men and women'. Most likely, the 'good men and women' were burghers who had a certain standing in society. They are likely to have been married or widowed. They were considered to be honourable and also appear to have been happy to get involved in maintaining social order. The role of the women was perhaps similar to that of the Protestant wives and widows

\footnotetext{
${ }^{9}$ Kossmann-Putto, 'Stadsbestuur', 61-2; Lange, Excommunication for Debt, 212.

${ }^{10}$ Between 1424 and 1500 only 136 individuals were active as aldermen and councillors.

${ }^{11}$ Kossmann-Putto, Kamper schepenacten, 4, 5, 7.

${ }^{12}$ Ibid., 8.
} 
of the Languedoc region who positioned themselves as moral guardians by speaking out against immoral behaviour. ${ }^{13}$ The 'good men and women' of Kampen appear to have acted as the conscience of the population as a whole and could affect the outcome of a legal case positively or negatively as will become clear in various examples in the following chapters. Over and above that, the population of Kampen can be divided between burghers or citizens and other inhabitants. Access to citizenship rights does not appear to have been very restrictive, though in 1478 it was laid down that new citizens had to be approved by the council. ${ }^{14}$ Normally, a fee was also paid. ${ }^{15}$ Most craftsmen and merchants would have been burghers. Other inhabitants included recent migrants, servants, marginal individuals like sex workers and others who could not afford the fee.

The Kampen magistrates in the second half of the fifteenth century made use of several registers to record their administration of justice. An important role was played by the town clerk in keeping this administration. With the exception of collections of by-laws and a fourteenth-century liber memorialis (the Oudste Foliant), legal records are extant from 1447. ${ }^{16}$ One of the main sources for information on banishments is the register of 'fugitives and banished outcasts' ('voirtvluchtige \& uutgelegde ballinge'). ${ }^{17}$ This is dedicated mainly to recording people who had fled (and had been declared banished as a result) or those who had been banished because they had been unable to pay their fines. A similar administration had already been kept in the fourteenth century: there is apparently a separate section in the Oudste Foliant recording fugitives and banished outcasts,

${ }^{13}$ Lipscomb, Voices of Nîmes, 147.

${ }^{14} \mathrm{DN}$, f. $27 \mathrm{v}$.

${ }^{15}$ As far as I am aware, no specific study has been undertaken on the exact rights of Kampen burghers, though it is clear from the regulations in the DN that they included access to certain common areas (e.g. DN, f. 25v (1485)). More generally on citizenship, see Prak, Citizens without Nations.

${ }^{16}$ A liber memorialis is an urban register (German: Stadtbuch; Dutch: stadboek) in which town clerks recorded various aspects of government and legal administration which the magistrates considered worthy of remembrance. In fourteenth-century Kampen there were two: the Oudste Foliant and its, now lost, predecessor the Liber Vetus. Some of the Oudste Foliant has been published in Kossmann-Putto, Kamper schepenacten. Kossmann-Putto, 'Stadsbestuur van Kampen', 63.

${ }^{17}$ Reg, pp. 78-216 (1447-1578). The register of banishments has been bound in with the register of 'oerveden', the register of capital offenders, the 'jaarkeur' (for all, see below) and 'schadeloos' (warranty against damages). 
and it is likely that the book's predecessor included a similar list. ${ }^{18}$ The register includes names and offences and, in a majority of cases, the fine due. It may also include the offender's occupation and provenance, a victim (where relevant), the scene of the crime and aggravating circumstances. Such circumstances could be that an offence had taken place at night, which meant a doubling of the fine, or within a designated area of the town, that is to say the area around the town hall, which also resulted in a higher penalty.

There are two extant registers which include actual court cases: the Digestum Vetus and the Liber Causarum. ${ }^{19}$ The Liber Causarum runs from 1475 to 1604 and is dedicated to legal cases, criminal, civil and voluntary. A separate register recording capital and corporal offences was set up around $1480 .{ }^{20}$ Such offences are also included in the Digestum Vetus, a liber memorialis dated 1454-73, in addition to other legal cases, by-laws and entries on notable events. The Digestum Vetus adds an extra layer of information through the inclusion of a large number of illustrations, which will be discussed in more detail below.

Also relevant is the register of 'oerveden', oaths foreswearing violence to the town, its inhabitants or representatives. ${ }^{21}$ These oaths were sworn by people who had spent some time in custody in one of Kampen's prisons, and were often, though not always, also punished by either flogging, the pillory, banishment or mutilation, or a combination of these.

${ }^{18}$ Kossmann-Putto, 'Stadsbestuur van Kampen', 65. I was unable to locate this section in the digital images of part of the manuscript and it was not possible to view the manuscript in person because of travel restrictions.

${ }^{19} \mathrm{DV}$ (the first 12 folios have been lost; the Digestum also includes entries from 1448 , $1453,1474,1475,1476$ and 1478)); LC. In this study, the references to the DV use the original foliation. The manuscript was recently renumbered, but I was unable to check the new foliation as a result of travel restrictions.

${ }^{20} \mathrm{Reg}$, pp. 217-310 (1480-1533). As the Liber Causarum does not include any capital offences, it is possible that a separate register was already started in 1475 .

${ }^{21}$ Reg, p. 1-77 (1477-1568). Similar oaths were common in other parts of Europe, such as the Urfehden in Germany. With regard to Germany, see, for example, Boockmann, Urfehde und ewige Gefangenschaft, and Blauert, Das Urfehdewesen. Blauert differentiates between the 'Hafturfehde', which is the type used in Kampen, and the 'Streiturfehde', which was an older form in which the oath taker foreswore violence against the opposing party. With regard to Germany and the Netherlands (especially Kampen's neighbour Deventer), see: Benders, Bestuursstructuur, 155-168. Concerning the older form in France (asseurement) and in Scotland (lawburrows) respectively, see Cohen, 'Violence control in late medieval France', 112; G.B. Clark, 'The remedy of lawburrows in Scots law', unpublished LL.M. thesis, University of Edinburgh, 1985, cited by Ewan, 'Disorderly damsels', 158. 
Unfortunately, the majority of entries does not include information on the oath taker's crimes. The most important aspect for the magistrates was obviously the fact that someone foreswore violence. A breaking of this oath could result in severe punishment, as is apparent from the case of a man who broke his oath in 1471: Wolter Krauwel was banished from Kampen for life at a distance of ten miles. ${ }^{22}$

An interesting register is that of the 'jaarkeur'. ${ }^{23}$ This documents arrangements for the payment of fines in instalments between the town council and individual offenders. Many inhabitants were unable to pay their fines in the first instance, as is also suggested by the fact that people were banished in large numbers for not paying. But the magistrates did offer offenders the opportunity to pay their fine in instalments. In addition, banished inhabitants could arrange (or have arranged for them) a payment plan which would allow them to return to Kampen. Lists of fines are also included in the Liber Testium (1483-93) and in the only extant fifteenth-century town account (1472-94). ${ }^{24}$ The latter also includes lists of the people who had to pay an instalment of their jaarkeur for every year. Overall, the town magistrates kept quite a thorough financial administration of any fines due to them, in addition to a range of legal records.

\section{The Illustrations in the Digestum Vetus}

The Digestum Vetus provides us with some unique insights into late medieval Kampen society, not only through its contents, but also through a large number of illustrations. These were most likely added by the town clerk, Peter Henricsz, who was appointed around 1444 and who died in $1478 .{ }^{25}$ More than 260 pen drawings are included in the manuscript, all of which are related to an element in the accompanying entry. Some show a material object that is relevant to the contents, like a ship accompanying an entry about the freighting of goods to Bergen, or a church tower, a crossbow, a cow and laundry illustrating a by-law proscribing shooting at the church tower and using the cemetery as a meadow or bleaching field (see Fig. 2.1). Others show people, such as a monk when an entry

\footnotetext{
${ }^{22}$ Reg, p. 12 (1471).

${ }^{23}$ Reg, pp. 372-451 (1465-1514). The jaarkeur concerns the payment in annual instalments of fines and debts. A similar administration appears to have existed in Deventer, where it was known as 'jaargeld'. Benders, Bestuursstructuur, 171-172.

${ }^{24} \mathrm{LC}$; SR.

${ }^{25}$ De Boer and Frankot, 'Digestum digitaal', 44, 47; Schilder, Digestum Vetus, 5-7.
} 


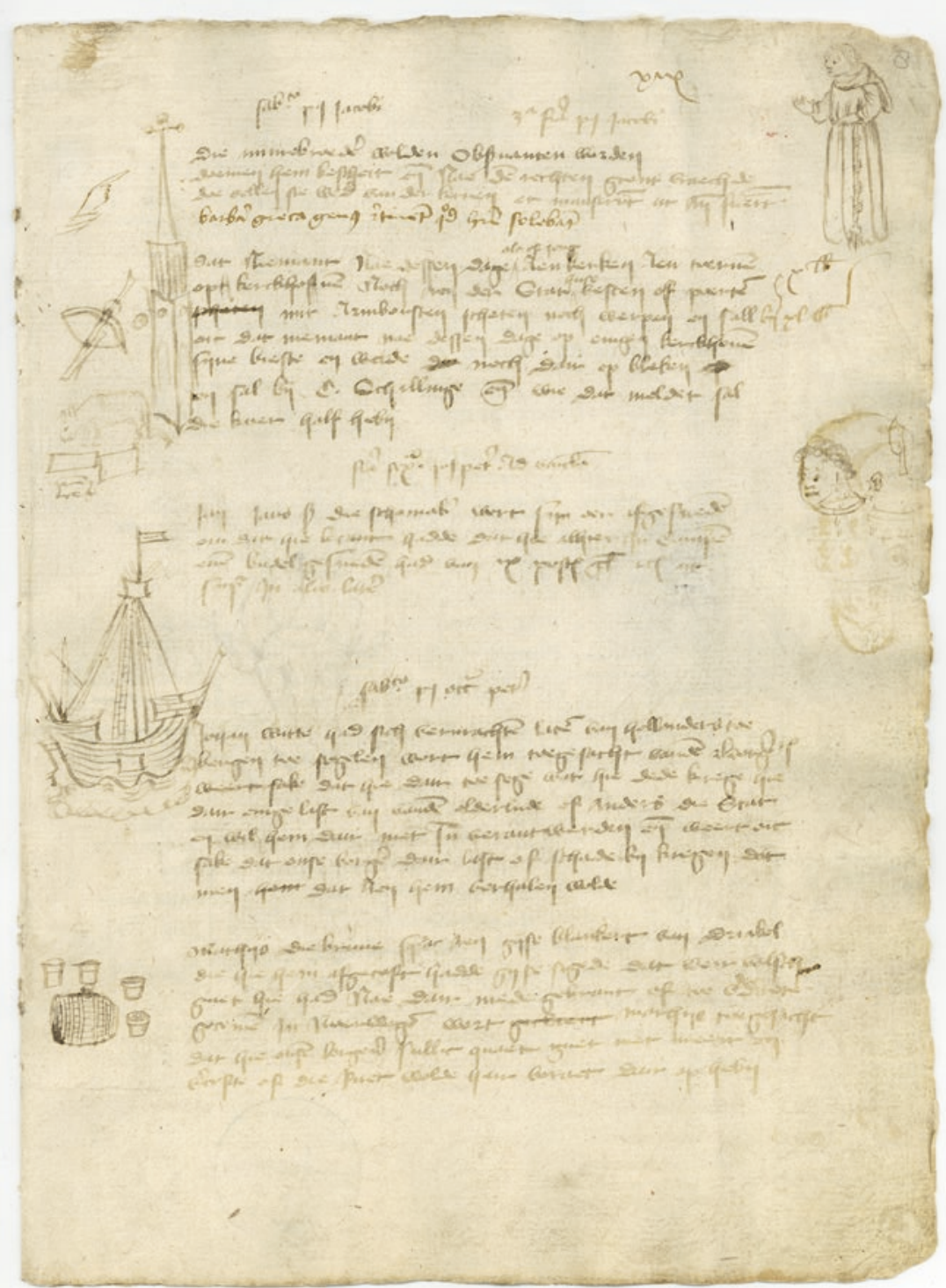

Fig. 2.1 Example of a full page with illustrations in the Digestum Vetus (DV, f. 19r). (C) Stadsarchief Kampen, Nederland/(C) City Archives Kampen, the Netherlands) 
discusses the wish of the Franciscans to become Observants (see Fig. 2.1), persons conducting an activity that is discussed, such as brewing, or speeding with their carts, or criminals being subjected to punishment, such as the man who is mutilated by having his ear cut off (see Fig. 2.1), a man being flogged at the pillory (see Fig. 3.3) or a group of people being exposed on the 'kaak', a large pillory (see Fig. 3.1). From the illustrations that we have of the 'kaak' and the pillory at which people were flogged, these appear to have been two separate structures. There are also images of gallows and wheels, mostly drawn quickly and with less detail than most of the illustrations in the manuscript. Highly interesting, finally, are the portraits that have been included illustrating some of the court cases (see e.g. Figs. 4.2, 4.3 and 5.1). These show the defendants, often depicted with their eyes lowered, suggesting their humility before the court. This depiction is more likely an expression of what the clerk considered to be the correct attitude towards appearing before the court, especially in cases of immoral behaviour, than an accurate portrayal of the defendants' demeanour.

The pen drawings are unique in their wide-ranging depiction of late medieval urban life in a legal register. There are a number of possible reasons for their inclusion in this manuscript. Most obviously, Peter Henricsz had creative talent and a love of drawing. Occasional drawings can be found in other late medieval legal registers, but nowhere to this extent. But it most likely also had something to do with the nature of the contents of this manuscript. The Digestum Vetus is not the only register that was kept during Henricsz's time, but only this manuscript includes so many drawings. In the Digestum Novum, a register of by-laws, for example, there are only seven small drawings. ${ }^{26}$ The Liber Diversorum $C$ also includes illustrations depicting various objects relevant to the professionals hired by the town council. ${ }^{27}$ It is possible that Henricsz was inspired by the contents of the Digestum Vetus to such an extent that he included drawings on many of its pages. The illustrations might in addition have

${ }^{26} \mathrm{DN}$, ff. $8 \mathrm{r}$ (dice), 8v (cart), 9r (goose), 16r (large pitcher), 2lv (dog), 22v (dog), 28v (fish), all drawn during Henricsz lifetime.

${ }^{27}$ I have only seen a small number of pages from this particular manuscript, namely those concerning the executioner (including a sword) and 'stokmeester' (including an image of the stocks), which pages also include entries on the horn blower (with images of horns), the person in charge of the town's guns (with an image of a gun), the bowmaker (including a crossbow) and the harness maker (including a chain mail). It is likely that similar drawings are included elsewhere in this manuscript. LD, ff. 170r, 189r, 195v, 196r, 196v. 
assisted in locating particular entries more quickly when information needed to be found. As such, they may have been of practical use as well. In addition, they can be considered to be representations of the urban identity of the magistrates as propagated by the town clerk. ${ }^{28}$ In the context of this study, it is useful to analyse the illustrations concerning punishment and the mentioned portraits of miscreants, as these provide an extra layer to our knowledge of the perception of offenders and the representation of public power through punishment. ${ }^{29}$ This will be discussed further in the relevant sections below.

\section{LEgAl CONTEXT}

Before turning to the regulations issued by the Kampen town council in the fourteenth and fifteenth centuries, it would be useful to give a brief overview of the historical and theoretical background of banishment in the Low Countries. There is, of old, a difference between banishment (verbanning) and outlawry (vredeloosheid). An outlaw would lose all rights, and be considered an enemy to society. An exile, on the other hand, was ousted from a territory for a limited or unlimited time and had to swear not to return during that time. The goal of banishment was to remove a person from a specific place where they were considered to be a menace. An exile did not lose any rights and could normally return to enjoy his or her property and business and familial relationships when certain conditions had been met. Another difference between banishment and outlawing was that the former was an actual punishment, whereas the second was a sanction relating to a lawsuit. The accused had broken the rules, either by failing to appear in court or by proving themselves unwilling to be subjected to a punishment. In practice both banishment and outlawing resulted in the exclusion from a community. ${ }^{30}$

According to Van Caenegem, the Old-Flemish laws allowed for temporary or redeemable outlawing. This meant that it was possible for an outlaw to end their exile by appearing in court or paying off a fine or debt. A

${ }^{28}$ De Boer and Frankot, 'Digestum digitaal', 40.

${ }^{29}$ See also the sixteenth-century drawings from Ulm depicting punishments, as discussed by Coy, Strangers and Misfits, 130, plus images on 13, 48, 78, 131.

${ }^{30}$ Van Caenegem, Geschiedenis van het strafrecht, 137-9, 146. Benders, Bestuursstructuur, 177; Napran, 'Introduction', 4. Concerning the early vocabulary of exile and outlawry, see Van Houts, 'Vocabulary of exile'; concerning terminology used in France and England, see also Jacob, 'Bannissement', 1039. 
specific practice of banishment appears to have developed within autonomous towns. Banishment was, with fining, the main punishment meted out within the urban jurisdiction of the later middle ages. As a result of the specific organisational and legal form of urban society as a community based (at least principally) on solidarity, freedom and equal rights and duties within a restricted territory, any member of this community who did not cooperate or even actively opposed collaboration was excluded and ejected from it. ${ }^{31}$ Van Caenegem differentiates between banishment as the main punishment, as a coercive measure and as an additional punishment. Coercive banishments for the non-payment of fines were a regular occurrence in Flemish towns. ${ }^{32}$ Van Caenegem notes the practical similarity to redeemable outlawry. The situation in Kampen appears to have been quite similar to that described by Van Caenegem. Even though the terminology around outlawry (vredeloosheid, etc.) was not used in fifteenthcentury Kampen for offenders who fled justice (not even those charged with manslaughter), a type of redeemable outlawry whereby an exile could be ended by the payment of a fine seems to have been in use here as well. There is also one example in which a man appears to have been outlawed, although this is not stated explicitly. Johan van Ensz was declared a 'perjurious traitor' ('menedigen verraeder') after having acted against the town and its citizens and broken his oervede oath. A bounty was put on his head: anyone who would be able to bring him to justice would receive 100 gold guilders. Dead, he was worth 50 guilders. ${ }^{33}$ Banishments were also used as a means of coercion like in the Flemish towns. With regard to manslaughter, offenders were not made wholly lawless. This is different to the practice in Holland and Zeeland in the same period. There, an escaped manslaughterer who did not appear in court on four separate occasions would be outlawed, lost all or part of his goods and could be killed by the victim's relatives with impunity. ${ }^{34}$

With regard to the terminology used in the Kampen sources, there are a few points to stress. The register apparently records 'voirtvluchtige en uutgelegde ballinge': exiles on the run (fugitives) and banished exiles. The terms 'voirtvluchtich' and 'uutgelacht' are subsequently used to describe many of the offenders in the registers, either together or individually. In a

\footnotetext{
${ }^{31}$ Van Caenegem, Geschiedenis van het strafrecht, 154-5.

${ }^{32}$ Ibid., 148, 224-5.

${ }^{33}$ Reg, p. 234 (no date, after 1493). See also LC, f. 37v (1493); Reg, p. 24 (1493).

${ }^{34}$ Glaudemans, Om die wrake wille, 170 and table on pages $335-6$.
} 
small number of cases other descriptions are used, such as 'die stat verboden' ('banned from the town'). The use of the terms 'voirtvluchtich' and 'uutgelacht', both together and separately, suggests that these were deployed deliberately to differentiate between offenders who fled and those who were banished. This is confirmed by an entry in which only the words 'voirtvluchtig ende' have been deleted, leaving 'uutgelacht'. ${ }^{35}$ However, it is difficult to detect the reasoning behind assigning one or the other, or both, in the recorded entries. One would expect a fugitive to also have been declared banished in absentia, but this is not always the case. Also, offenders that are said to have failed to appear in court are sometimes recorded as being banished and at other times as a fugitive and exile. ${ }^{36}$ Notable, in this regard, is the entry from 1447 in which a man was declared banished for pulling out a knife, whereas three others were named as fugitives for failing to bring him to court to answer for his offence. Obviously the first man had also chosen not to appear in court, but he was not called 'voirtvluchtich'. ${ }^{37}$ Moreover, in 1452 two men had been involved in the wounding of each other. The first was 'voirtvluchtich ende uutgelacht', the second only 'voirtvluchtich'. Both were penalised in the same way for the wounding: they had forfeited a hand or had to pay 200 pounds. It appears then that both were sentenced in absentia. Even the men who had (accidentally) killed someone were variously described as being fugitives or fugitives and exiles. According to a by-law, those guilty of manslaughter were banished until a reconciliation had taken place. It appears, then, that the offenders' status was not always recorded precisely, which suggests that, in practice, fugitives and exiles were considered to have been equal legally. ${ }^{38}$ This is confirmed by the use of the word 'balling' for both in some of the relevant by-laws and in the title of the banishment register. For that reason, the terms 'exile' and 'banishment' will be used for both groups. The word 'fugitive', on the other hand, will be used only

\footnotetext{
${ }^{35}$ Reg, p. 84.

${ }^{36}$ For example, Reg, p. 133.

${ }^{37}$ Reg, p. 79.
}

${ }^{38}$ This was not the case in the German towns studied by Maurer where, even though both are recorded side by side, a legal differentiation was made between 'Acht' and 'Verfestung' on the one side and 'Verbannung' and 'Verweisung' on the other. Maurer, 'Erzwungene Ferne', 200-201. 
to denote those who had fled justice, as some of the by-laws discussed below specifically refer to that group of exiles. ${ }^{39}$

\section{BY-LAWS}

The Kampen by-laws were recorded mainly in three registers. The Boeck van Rechte was compiled in the second half of the fourteenth century, though its oldest dated regulation is from 1313. Its successor, the Gulden Boeck, was started in the early fifteenth century. ${ }^{40}$ From 1450 new by-laws were recorded every year in the Digestum Novum. ${ }^{41}$ In 1334 a large number of by-laws were recorded in what are called the 'eerste' and 'andere brieff' (meaning the first and second decree or proclamation), which were copied into the Gulden Boeck. These were read out to the population annually to inform them of the communal laws. ${ }^{42}$ These decrees stipulated with regard to fines that whoever was unable to pay a fine would be flogged and subsequently banished until the time that the fine was paid. If the fine was as low as $2 \mathrm{lb}$., a flogging would suffice. This law applied to both burghers and visitors of Kampen. Women would have carried the stone (a yoke with a stone on either side (see Fig. 3.2)) instead of being flogged. ${ }^{43}$ It is possible that the flogging was dispensed with at a later time, or was perhaps never executed in practice, as there is no evidence of it being used as an alternative to a $2 \mathrm{lb}$. fine in the sources from the second half of the fifteenth century. By that time people were banished for failing to pay even these fines. ${ }^{44}$

39 'Exile' is here not used in the sense of a banishment, often to a specific place, of a person for political reasons. For this use, see, for example, Van Houts, 'Preface', xi, and Maurer, 'Erzwungene Ferne', 206. Tyler, 'Refugees and reform', 78, points out that one might use 'exile' to denote the expulsion of a citizen, and 'banishment' to indicate that of a non-citizen or foreigner, but that this does not correspond to the terminology used in the sources. He also notes that, linguistically, it has thus far been impossible to differentiate between the various terms used in late medieval and early modern Augsburg with regard to banishment. There, various terms appear to have been used interchangeably.

${ }^{40}$ BvR; GB. Kossmann-Putto, Kamper schepenacten, 11; Overijsselsche Stad-, Dijk-en Markeregten, vii.

${ }^{41} \mathrm{DN}$.

${ }^{42}$ Kossmann-Putto, 'Stadsbestuur van Kampen', 66.

${ }^{43} \mathrm{~GB}$, f. 39v.

${ }^{44}$ For example: Geert Assensoen was banished in 1453 for a fine of $2 \mathrm{lb}$. resulting from an insult of a woman (Reg, p. 87 (1453)). Similarly, Geertken Walravens was banished for a $2 \mathrm{lb}$. fine for punching someone in 1464 (Reg, p. 103 (1464)). 
In 1352 it was laid down that anyone who fled after a perpetrated offence, be it a breaking of the peace or something else, would be considered guilty of the offence. ${ }^{45}$ As such, any fines due for this particular offence would have to be paid before the fugitive would be allowed to re-enter the town. Whoever returned after banishment without authorisation would be due an additional $80 \mathrm{lb}$. fine, as would those that housed him or her. ${ }^{46}$ Half this fine would be meted out to those banished as a result of an unpaid debt. ${ }^{47}$ So, although no by-law has survived specifically outlining this, one could also get banished for debts to the city, for example as a result of the lease of property or fishing rights. This is confirmed by some examples in the sources from practice. ${ }^{48}$ Fines for illegal return also existed elsewhere, such as in medieval Fritzlar, where the elite was actually meted out a higher fine for a return than the lower social classes. ${ }^{49}$

In the fifteenth century some by-laws were issued with regard to the property of fugitives and exiles. In 1445 it was stipulated, among other things, that when someone fled after a crime, the Kampen magistrates could confiscate any of their goods to pay for the fine. Also, if the offender was renting a property, the owner would be allowed to use anything inside the house to recover the loss of rental payments. ${ }^{50}$ To prevent the loss of their goods, exiles most likely tried to remove the contents from their house before these could be confiscated, particularly if they were not intending to return to Kampen. As especially those fleeing from justice would have been in a hurry to leave town, they would generally have needed assistance with this. In 1470 it was laid down in the Gulden Boeck that anyone helping fugitives by transporting their household and other goods out of town (either by road or by sea) would risk a fine of $80 \mathrm{lb} .^{51}$ In 1477 it was added that any fugitives trying to take away or hide any of their goods from their debtors would lose their citizenship, in addition to

\footnotetext{
${ }^{45} \mathrm{BvR}$, f. 37v; GB, f. $42 \mathrm{r}$ (1352).

${ }^{46}$ Some additional by-laws concerning the unauthorised return to Kampen of exiles are discussed below.

${ }^{47} \mathrm{~GB}$, f. $42 \mathrm{v}$ (1334).

${ }^{48}$ For example: Tyman Claesz had 'mijnt' (bought by auction) the 'stadswatere', but failed to come up with the full amount. He was banished in 1483 (Reg, p. 130 (1483)). He eventually arranged to pay off his debt in instalments between 1485 and 1492 (Reg, p. 387 (1485)).

${ }^{49}$ Von Brockdorf, 'Die Strafe des Stadtverweises', 47.

${ }^{50} \mathrm{~GB}$, f. $105 \mathrm{r}$ (18 September 1445).

${ }^{51} \mathrm{~GB}$, f. $48 \mathrm{v}$ (1446).
} 
a fine of $80 \mathrm{lb}$. They would be banned from becoming burghers for six years. Anyone assisting them in hiding their goods would be fined $80 \mathrm{lb}$. Any person looking after any property of the fugitive in their home had to notify the magistrates as soon as they heard about the banishment, on punishment of $80 \mathrm{lb}$. This property would also be used to pay off any debts. ${ }^{52}$

From these by-laws it becomes clear that fugitives did not lose the rights to their property, though they were not allowed to remove it from the town until any debts were paid. Parts of it could be confiscated. They also did not lose their citizenship. There are no by-laws regulating the property of other exiles, which suggests that they did not lose any rights concerning them and may also have been allowed to take their goods. It appears that all exiles were, in principle, expected to eventually return to Kampen, unless they were, of course, banished for life. In Utrecht, too, exiles could continue to own property in the city, and their goods could be confiscated to offset any damages. ${ }^{53}$ The repeated by-laws from the 1470 s, banning any help to fugitives, also indicate that they were receiving help from friends and family inside the town after their flight. The same was the case in Holland and Zeeland where exiles were receiving support despite laws proscribing it. ${ }^{54}$

${ }^{52} \mathrm{~GB}$, f. $48 \mathrm{v}$ (11 December 1477).

${ }^{53}$ Berents, Misdaad in de Middeleewwen, 148-9.

${ }^{54}$ Glaudemans, Om die wrake wille, 200. 
Open Access This chapter is licensed under the terms of the Creative Commons Attribution 4.0 International License (http://creativecommons.org/licenses/ by $/ 4.0 /$ ), which permits use, sharing, adaptation, distribution and reproduction in any medium or format, as long as you give appropriate credit to the original author(s) and the source, provide a link to the Creative Commons licence and indicate if changes were made.

The images or other third party material in this chapter are included in the chapter's Creative Commons licence, unless indicated otherwise in a credit line to the material. If material is not included in the chapter's Creative Commons licence and your intended use is not permitted by statutory regulation or exceeds the permitted use, you will need to obtain permission directly from the copyright holder. 